\title{
Methyl halide emissions from savanna fires in southern Africa
}

\author{
M. O. Andreae, ${ }^{1}$ E. Atlas, ${ }^{2}$ G. W. Harris, ${ }^{1,3}$ G. Helas, ${ }^{1}$ A. de Kock, ${ }^{4}$ R. Koppmann, ${ }^{5}$ \\ W. Maenhaut, ${ }^{6}$ S. Manø, ${ }^{1}$ W. H. Pollock, ${ }^{2}$ J. Rudolph, ${ }^{5}$ D. Scharffe, ${ }^{1}$ G. Schebeske, ${ }^{1}$ \\ and $\mathrm{M}$. Welling ${ }^{1}$
}

\begin{abstract}
The methyl halides, methyl chloride $\left(\mathrm{CH}_{3} \mathrm{Cl}\right)$, methyl bromide $\left(\mathrm{CH}_{3} \mathrm{Br}\right)$, and methyl iodide $\left(\mathrm{CH}_{3} \mathrm{I}\right)$, were measured in regional air samples and smoke from savanna fires in southern Africa during the Southern Africa Fire-Atmosphere Research Initiative-92 (SAFARI-92) experiment (August-October 1992). All three species were significantly enhanced in the smoke plumes relative to the regional background. Good correlations were found between the methyl halides and carbon monoxide, suggesting that emission was predominantly associated with the smoldering phase of the fires. About $90 \%$ of the halogen content of the fuel burned was released to the atmosphere, mostly as halide species, but a significant fraction (3-38\%) was emitted in methylated form. On the basis of comparison with the composition of the regional background atmosphere, emission ratios to carbon dioxide and carbon monoxide were determined for the methyl halide species. The emission ratios decreased in the sequence $\mathrm{CH}_{3} \mathrm{Cl}>\mathrm{CH}_{3} \mathrm{Br}>\mathrm{CH}_{3} \mathrm{I}$. Extrapolation of these results in combination with data from other types of biomass burning, e.g. forest fires, suggests that vegetation fires make a significant contribution to the atmospheric budget of $\mathrm{CH}_{3} \mathrm{Cl}$ and $\mathrm{CH}_{3} \mathrm{Br}$. For tropospheric $\mathrm{CH}_{3} \mathrm{I}$, on the other hand, fires appear to be a minor source. Our results suggest that pyrogenic emissions of $\mathrm{CH}_{3} \mathrm{Cl}$ and $\mathrm{CH}_{3} \mathrm{Br}$ need to be considered as significant contributors to stratospheric ozone destruction.
\end{abstract}

\section{Introduction}

Before the onset of the large-scale production and emission of halogenated substances, particularly the chlorofluorocarbons and halons, methyl chloride $\left(\mathrm{CH}_{3} \mathrm{Cl}\right)$ and methyl bromide $\left(\mathrm{CH}_{3} \mathrm{Br}\right)$ were the dominant sources of halogen compounds to the stratosphere. Even as late as 1950 , the photodecomposition of $\mathrm{CH}_{3} \mathrm{Cl}$ provided some $85 \%$ of stratospheric chlorine, and only around the year 1970 did industrially produced organochlorine compounds begin to overtake $\mathrm{CH}_{3} \mathrm{Cl}$ as a source of stratospheric chlorine [Weisenstein et al., 1992]. In spite of the obvious importance of $\mathrm{CH}_{3} \mathrm{Cl}$ for the stratospheric ozone budget, its sources are not well quantified. Up to quite recently, the ocean was generally considered to be the dominant source of $\mathrm{CH}_{3} \mathrm{Cl}$ [Rasmussen et al., 1980; Singh et al., 1983; World Meteorological Organization (WMO), 1985, 1992]. However,

\footnotetext{
'Biogeochemistry and Air Chemistry Departments, Max Planck Institute for Chemistry, Mainz, Germany.

${ }^{2}$ Atmospheric Chemistry Division, National Center for Atmospheric Research, Boulder, Colorado.

${ }^{3}$ Now at Centre for Atmospheric Chemistry, York University, North York, Ontario, Canada.

${ }^{4}$ Department of Oceanography, University of Port Elizabeth, South Africa.

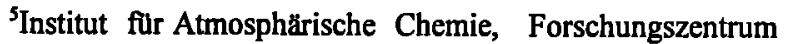
Jülich (KFA), Jülich, Germany.

${ }^{6}$ Institut for Nuclear Sciences, University of Gent, Gent, Belgium.
}

Copyright 1996 by the American Geophysical Union.

Paper number 95JD01733.

0148-0227/96/95JD-01733\$09.00 the emission of $\mathrm{CH}_{3} \mathrm{Cl}$ from biomass burning had been noted already in the early 1970 s, when this substance was first discovered in the atmosphere [Lovelock, 1975]. Since then, a number of authors measured $\mathrm{CH}_{3} \mathrm{Cl}$ in smoke from biomass fires [Palmer, 1976; Crutzen et al., 1979; Rasmussen et al., 1980; Tassios and Packham, 1985; Lobert et al., 1991; Laursen et al., 1992]. On the basis of these results, and of estimates of the global amounts of biomass burned annually [Crutzen and Andreae, 1990; Hao et al., 1990], the global annual $\mathrm{CH}_{3} \mathrm{Cl}$ emission from biomass burning was estimated to be $1.8 \pm 0.9 \mathrm{Tg}$ $\mathrm{CH}_{3} \mathrm{Cl} \mathrm{\textrm {yr } ^ { - 1 }}$ [Andreae, 1993]. From the mean atmospheric concentration of $\mathrm{CH}_{3} \mathrm{Cl}$ (600 parts per trillion (ppt)) and its lifetime of 1.56 years [Weisenstein et al., 1992], a total $\mathrm{CH}_{3} \mathrm{Cl}$ source strength of $3.4 \mathrm{Tg} \mathrm{yr}^{-1}$ can be derived. Consequently, biomass burning may represent up to one half of the estimated global emission of this trace gas [Andreae, 1993; Rudolph et al., 1995].

A similar situation applies in the case of $\mathrm{CH}_{3} \mathrm{Br}$, which was the only significant source of stratospheric bromine until the 1970 s, when large amounts of the bromofluorocarbons (halons) began to be emitted. Today, $\mathrm{CH}_{3} \mathrm{Br}$ still accounts for about one half of the bromine flux into the stratosphere [Schauffler et $a l ., 1993]$, a fraction which is likely to increase owing to the phase-out of the halons under the Montreal Protocol. The major sources of $\mathrm{CH}_{3} \mathrm{Br}$ are ocean emissions, biomass burning, agricultural usage, and automobiles [United Nations Environment Program (UNEP), 1992; WMO/UNEP, 1995]. Since $\mathrm{CH}_{3} \mathrm{Br}$ can be formed during combustion in the same way as $\mathrm{CH}_{3} \mathrm{Cl}$ (by reaction of halogen atoms with methyl radicals in the flame gases), its emission from biomass burning had been predicted, and was first observed experimentally by Andreae et al. [1993] and Mano and Andreae [1994]. On the basis of their results, they estimated that pyrogenic emission of $\mathrm{CH}_{3} \mathrm{Br}$ accounts for about one third of its global source strength of 
$\sim 100 \mathrm{Gg} \mathrm{yr}^{-1}$. In spite of the much lower emission flux and concentration of $\mathrm{CH}_{3} \mathrm{Br}$ as compared to $\mathrm{CH}_{3} \mathrm{Cl}$, bromine compounds represent a significant sink for stratospheric ozone because of the much higher (by at least a factor of 50) efficiency of the catalytic cycles involving bromine. Because of the ongoing reduction in the emission of the synthetic chlorofluorocarbons and bromofluorocarbons, the relative importance of $\mathrm{CH}_{3} \mathrm{Br}$ for stratospheric ozone loss is expected to increase. Furthermore, owing to the short atmospheric lifetime of $\mathrm{CH}_{3} \mathrm{Br}(1.3-2.0$ years [WMO/UNEP, 1995]), a significant reduction in its emission would have a relatively prompt effect on stratospheric bromine levels. The sources and atmospheric behavior of $\mathrm{CH}_{3} \mathrm{Br}$ have therefore been the subject of considerable discussion in recent years [UNEP, 1992; WMO/UNEP, 1995], and it has been pointed out that improved estimates of the various source terms are urgently needed.

In this paper, we present data on the emission of the methyl halides, $\mathrm{CH}_{3} \mathrm{Cl}, \mathrm{CH}_{3} \mathrm{Br}$, and $\mathrm{CH}_{3} \mathrm{I}$, from savanna fires in southern Africa. These results were obtained during the IGAC/ BIBEX (International Global Atmospheric Chemistry/Biomass Burning Experiment) campaign SAFARI-92 (Southern Africa Fire-Atmosphere Research Initiative-92), which took place during the 1992 fire season (August to October). The results will be placed in the context of the total emission of these compounds from all types of biomass burning and from other sources in order to assess the role of savanna fires in the atmospheric methyl halide budget.

\section{Methods}

During SAFARI-92, four laboratories made measurements of methyl halides in ambient air and in smoke from savanna fires: the Max Planck Institute for Chemistry in field laboratories located at Kruger Park (MPIC-K) and in Pretoria (MPIC-P), the National Center for Atmospheric Research (NCAR), and the Forschungszentrum Jülich (KFA). The sampling and analysis procedures will be described only briefly in this paper; more details can be found in the papers by Atlas et al. [1993], E. Atlas et al. (manuscript in preparation, 1995), G. Helas et al. (manuscript in preparation, 1995), and R. Koppmann et al. (manuscript in preparation, 1995).

\section{Sampling}

Air samples were collected in stainless steel canisters. NCAR used cylindrical stainless steel canisters with a volume of $2.5 \mathrm{~L}$, MPIC-P and KFA cylindrical canisters with a volume of $2.0 \mathrm{~L}$, and MPIC-K spherical canisters with a volume of $1.0 \mathrm{~L}$. All canisters are electron beam welded and electropolished inside and equipped with metal bellows valves and had been cleaned and tested for hydrocarbon and halocarbon measurements. Samples were collected at ground level (NCAR) by pressurizing the canisters with a metal bellows pump to about 3 bar in the smoke plume of the fires. On the research aircraft, a Cessna 310 (MPIC-K) and a DC-3 (MPIC-P, KFA), air was taken in using a continuously flushed stainless steel manifold and pumped into the canisters using metal bellows (DC-3) or Teflon membrane (Cessna) pumps. The sample collection took up to about $1 \mathrm{~min}$. The canisters were filled to a pressure of about 2-3 bar. On the DC-3, the water content of the air was reduced by passing the sample air stream through a trap cooled with ice. No detectable losses of the methyl halides or $\mathrm{CO}_{2}$ result from this drying procedure.

\section{Methyl Halide, $\mathrm{CO}$, and $\mathrm{CO}_{2}$ Determinations}

NCAR. Sample volumes of $0.1-1.0 \mathrm{~L}$ were preconcentrated on a glass bead trap at liquid argon temperature. The preconcentrated sample was transferred at $\sim 85^{\circ} \mathrm{C}$ to a $30 \mathrm{~m} \mathrm{x} 0.25 \mathrm{~mm} \mathrm{x}$ $1.0 \mu \mathrm{m}$ DB-1 capillary column held at $-65^{\circ} \mathrm{C}$. For separation, the column oven was held at $-65^{\circ} \mathrm{C}$ for $2 \mathrm{~min}$ and then ramped at $4^{\circ} \mathrm{C} \mathrm{min}^{-1}$ to $175^{\circ} \mathrm{C}$. A Hewlett-Packard 5971 mass selective detector in the selected ion mode was used for compound quantitation. Ions used for quantitation were as follows: $\mathrm{CH}_{3} \mathrm{Cl}$, $50 ; \mathrm{CH}_{3} \mathrm{Br}, 96$; and $\mathrm{CH}_{3} \mathrm{I}, 142$. A primary standard mixture of methyl halides was prepared by Scott Specialty Gases, and the mixing ratios were confirmed by analyses at the National Institute of Standards and Technology (NIST). CO was measured by gas chromatography (GC) using a $\mathrm{HgO}$ reductive gas detector. $\mathrm{CO}_{2}$ was determined on a separate aliquot of the samples using a gas chromatographic system which reduced $\mathrm{CO}_{2}$ to $\mathrm{CH}_{4}$ for quantitation by a flame ionization detector.

MPIC-K. Sample volumes of $60-600 \mathrm{~mL}$ air were preconcentrated by cryofocusing on a precolumn at $-186^{\circ} \mathrm{C}$. Separation was on a $25 \mathrm{~m}$ GS-Q column ( $0.35 \mathrm{~mm} \mathrm{ID})$ using $\mathrm{H}_{2}$ at $4 \mathrm{~mL} \mathrm{~min}^{-1}$ as carrier gas. A temperature program was used which consisted of $2 \mathrm{~min}$ at $30^{\circ} \mathrm{C}, 10^{\circ} \mathrm{C} \mathrm{min}-1$ to $150^{\circ} \mathrm{C}, 35^{\circ} \mathrm{C}$ $\mathrm{min}^{-1}$ to $220^{\circ} \mathrm{C}$, and $5 \mathrm{~min}$ isothermal at $220^{\circ} \mathrm{C}$. $\mathrm{CH}_{3} \mathrm{Cl}$ was quantified using a flame ionization detector. The separation system was checked and optimized thoroughly with potentially coeluting substances to eliminate interferences. Calibration in the field was by secondary standards consisting of compressed air, which had been calibrated in the laboratory using gravimetrically prepared static dilution standards. $\mathrm{CO}$ was measured by gas chromatography using a $\mathrm{HgO}$ reductive gas detector, $\mathrm{CO}_{2}$ by a non-dispersive infrared analyzer.

MPIC-P. Sample volumes of 0.1-0.3 L air were preconcentrated in a stainless steel tube filled with porous glass beads immersed in liquid argon. After preconcentration, the cold trap was immersed in boiling water and the samples were back-flushed from the trap to the GC column. The inlet of the column was held at liquid nitrogen temperature during the transfer to cryofocus the samples. The analytical column was a $50 \mathrm{~m} \times 0.32 \mathrm{~mm}$ Cp-Sil-5 fused silica capillary (Chrompack) with $1.2 \mu \mathrm{m}$ film thickness. The temperature program was as follows: $-40^{\circ} \mathrm{C}$ for $2 \mathrm{~min}$, a $15^{\circ} \mathrm{C} \min ^{-1}$ ramp to $40^{\circ} \mathrm{C}$, followed by a $10^{\circ} \mathrm{C} \mathrm{min}-1$ ramp to $200^{\circ} \mathrm{C}$. The GC used was a Siemens Sicromat II equipped with a flame ionization detector. The chromatograms were integrated using $\mathrm{ELAB}^{\oplus}$ chromatography software. A compressed air sample which had been calibrated by KFA was used as field standard. $\mathrm{CO}$ and $\mathrm{CO}_{2}$ were determined by KFA using the methods described below.

KFA. The samples were analyzed in the laboratory at Julich using gas chromatography with flame ionization (FID) and electron capture (ECD) detectors. Hydrocarbons and halocarbons were preconcentrated cryogenically and separated on a combination of a 7-m micropacked Porapak QS column and a 105 m RTX-1 fused silica capillary column. $\mathrm{CH}_{3} \mathrm{Cl}$ was evaluated from the ECD signal. Precision for this species is better than $10 \%$, the detection limit about $5 \mathrm{ppt}$. In a number of chromatograms, the $\mathrm{CH}_{3} \mathrm{Cl}$ peak overlapped with the water peak and could not be evaluated quantitatively. In some samples collected directly inside the smoke plumes, interferences with other peaks were observed (see also Rudolph et al. [1995]) which also precluded quantitative evaluation. $\mathrm{CO}$ and $\mathrm{CO}_{2}$ were determined by a gas chromatographic method very similar to the one described by Heidt [1978]. The precision is $3 \%$ for $\mathrm{CO}$ and 
$0.5 \%$ for $\mathrm{CO}_{2}$. Details of the analytical techniques are given by Koppmann et al. [1993] and Rudolph et al. [1995].

\section{Halogen Element Determination in Fuels and Residues}

The bulk (total) concentrations of the halogens in the savanna fuels and various fuel residues were determined by instrumental neutron activation analysis (INAA). Subsamples of $150 \mathrm{mg}$ were packed in polyethylene vials for INAA. The analysis for the elements $\mathrm{Cl}$ and I involved a 5-min irradiation of each subsample separately at a thermal neutron flux of 2-3 $\times 10^{12}$ neutrons $\mathrm{cm}^{-2} \mathrm{~s}^{-1}$ in the Thetis reactor of the University of Gent, after which the sample was subjected to two consecutive gamma spectrometric measurements (one of $5 \mathrm{~min}$ and one of $30 \mathrm{~min}$ ) with a high-resolution $\mathrm{Ge}$ detector. For the determination of $\mathrm{Br}$ we utilized a 7-hour neutron irradiation (up to six subsamples were irradiated simultaneously), and two measurements (of a few hours each) at 2 and 5 days after the irradiation. The net peak areas of selected $\gamma$ ray lines of the product radionuclides ${ }^{38} \mathrm{Cl},{ }^{82} \mathrm{Br}$, and ${ }^{128} \mathrm{I}$ were determined as described by Schutyser et al. [1978]. Concentration results were obtained from comparing these areas for the samples with those of multi-element standards. The standards had been prepared by pipetting solutions of the analyte elements onto Whatman filter paper.

\section{Results and Discussion}

\section{Sampling Sites}

During SAFARI-92, two types of samples were collected: smoke from experimental fires and from fires encountered during regional survey flights (Table 1), and ambient air from altitudes between $50 \mathrm{~m}$ (above ground level) and $4000 \mathrm{~m}$ (above sea level) over southern Africa (South Africa, Zimbabwe, Zambia, Botswana, Namibia, Angola, and Swaziland). The experimental fires were conducted in Kruger National Park (KNP), South Africa, and in sugarcane fields near Big Bend, Swaziland. All of the KNP fires were in sourveld savanna near Pretoriuskop, at the southern end of the park. This vegetation is relatively nutrient-poor, and had not been intensively grazed in spite of the intensive drought, which had prevailed in southern Africa for 2 years before the experiment. Additional information on the vegetation characteristics and fire behavior can be found in the papers by Trollope et al. [this issue] and Stocks et al. [this issue]. Two of the KNP fires were conducted in small plots (Shabeni 5 and Kabeni "Extra") with an area of about 6 ha each; these were sampled from the ground only. The two fires on the large management blocks 55 and 56 (2043 and 2333 ha, respectively) were sampled from the ground and with the Cessna 310 and DC-3 aircraft. Fires of opportunity were sampled by the DC-3 aircraft in the Drakensberg Escarpment, where a mixture of native forest, shrub, and grass was burning, and over a savanna fire in Zambia. The sugarcane fires, which were sampled by the DC-3, represent burns which are typical of regional agricultural practices. They are set immediately before harvesting in order to facilitate the cutting and processing of the sugarcane. This practice results in substantial levels of air pollution in many sugar-growing areas. During SAFARI-92, emissions from fires on two sugarcane fields of 12 and 43.7 ha area were investigated. The fires burned very intensively with large flames and consumed about 25 tons of dry mass per hectare.

In the following discussion, we will make use of the concept of emission ratios. This is necessary because the absolute concentration of trace gases in smoke samples has little meaning, since it simply represents varying degrees of dilution of flame gases with ambient air, an effect that is particularly pronounced in aircraft sampling, where the transit time through the plume is comparable to the sampling time. We will therefore analyze our data in the form of emission ratios, e.g.:

$$
E R_{\mathrm{CH}_{3} \mathrm{CrCO}}=\frac{\Delta \mathrm{CH}_{3} \mathrm{Cl}}{\Delta \mathrm{CO}}=\frac{\left(\mathrm{CH}_{3} \mathrm{Cl}\right)_{\text {Smoke }-\left(\mathrm{CH}_{3} \mathrm{Cl}\right)_{\text {Amblent }}}}{(\mathrm{CO})_{\text {Smoke }}-(\mathrm{CO})_{\text {Ambient }}}
$$

where $\mathrm{CO}\left(\right.$ or $\left.\mathrm{CO}_{2}\right)$ is used as reference species. The emission ratios are obtained by calculating the slope of the regression line between $\mathrm{CH}_{3} \mathrm{X}$ and $\mathrm{CO}$ (or $\mathrm{CH}_{3} \mathrm{X}$ and $\mathrm{CO}_{2}$ ) for a given data set from a fire or plume. Note that emission ratios are different from emission factors, which are defined as the amount of trace gas emitted per amount of fuel burned.

The selection of $\mathrm{CO}$ or $\mathrm{CO}_{2}$ as reference gas is determined by the final objective of the analysis. It has been shown previously [Lovelock, 1975; Lobert et al., 1991; Mano and Andreae, 1994] that $\mathrm{CH}_{3} \mathrm{Cl}$ is emitted preferentially in the smoldering stage of fires. $\mathrm{CO}$ is a suitable reference species for smoldering combustion, as it is also emitted predominantly

Table 1. Sampling Times and Locations for Smoke Samples Collected During SAFARI-92

\begin{tabular}{lcrl}
\hline Site & $\begin{array}{c}\text { Date } \\
(1992)\end{array}$ & $\begin{array}{c}\text { Number of } \\
\text { Samples }\end{array}$ & Laboratory \\
\hline Kruger Park & & & \\
$\quad$ Shabeni 5 & 15 Sept. & 4 & NCAR \\
$\quad$ Kabeni "Extra" & 22 Sept. & 3 & NCAR \\
$\quad$ Large block 56 & 18 Sept. & 25 & NCAR, MPI-K, MPI-P \\
$\quad$ Large block 55 & 24 Sept. & 38 & NCAR, MPI-K, MPI-P \\
Sugarcane field 1 & 19 Sept. & 5 & MPIC-P, KFA \\
Sugarcane field 2 & 19 Sept. & 3 & MPIC-P, KFA \\
Drakensberg near Belfast & 18 Sept. & 2 & MPIC-P, KFA \\
Drakensberg near Nelspruit & 20 Sept. & 12 & MPIC-P, KFA \\
Zambia savanna (16 ${ }^{\circ}, 2^{\circ}$ E) & 03 Oct. & 2 & MPIC-P, KFA \\
Ambient air & 15 Sept. to & 113 & MPIC-P, MPI-K, KFA, \\
& 06 Oct. & & NCAR \\
\hline
\end{tabular}




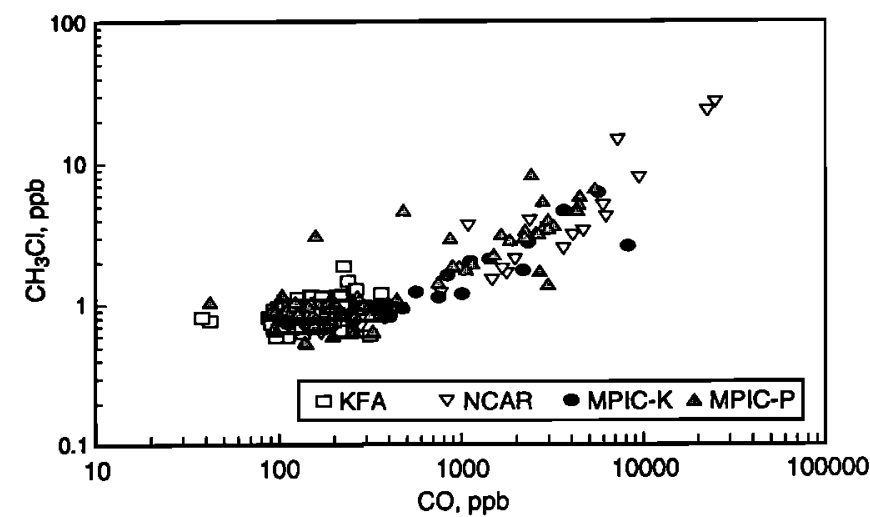

Figure 1. Methyl chloride concentrations in all samples collected during SAFARI-92 plotted against the corresponding CO concentrations.

during this stage [Lobert et al., 1991]. As a result, close correlations between smoldering-derived gases can usually be obtained, which allows accurate estimation of trace gas emissions from fires for which the $\mathrm{CO}$ emission is known. For smoldering-derived species, the emission ratio relative to $\mathrm{CO}$ is largely dependent on fuel characteristics, particularly the elemental composition (e.g., the halogen content) of the fuel. Correlations of these gases with $\mathrm{CO}_{2}$, on the other hand, tend to be relatively poor, since the relative proportion of flaming versus smoldering combustion in different fires or even different parts of the same fire results in variable trace gas to $\mathrm{CO}_{2}$ ratios. On the other hand, the emission ratio relative to $\mathrm{CO}_{2}$ permits the estimation of trace gas emission from fires for which only the amount of biomass burned, but not the amount of $\mathrm{CO}$ emitted, is known. Therefore this ratio is more suitable for regional or global estimations.

\section{Methyl Chloride}

The $\mathrm{CH}_{3} \mathrm{Cl}$ results from SAFARI-92 are shown in Figure 1 in the form of a scatterplot versus $\mathrm{CO}$, with the measurements by the different laboratories identified by different symbols. This figure shows that there is no obvious analytical bias between the data from the different groups. The ambient air samples cluster in the lower left corner of the figure, representing the $\mathrm{CH}_{3} \mathrm{Cl}$ and $\mathrm{CO}$ values typical of the lower $3 \mathrm{~km}$ of the atmosphere over southern Africa during SAFARI-92, about 0.6-1.1 ppb $\mathrm{CH}_{3} \mathrm{Cl}$ and 100-300 ppb CO. In the smoke samples, $\mathrm{CO}$ concentrations up to $26 \mathrm{ppb} \mathrm{CH}_{3} \mathrm{Cl}$ and $25 \mathrm{ppm} \mathrm{CO}$ were measured. This suggests that considerable dilution took place during sampling, since "pure" smoke from flaming and smoldering combustion contains hundreds to thousands of parts per million $\mathrm{CO}$.

When the results from the various fires are analyzed separately, we find a surprising degree of consistency betwẹen fires in widely varying fuel types. The $\mathrm{CH}_{3} \mathrm{Cl}$ values from the two small fire plots in KNP are plotted against $\mathrm{CO}$ in Figure 2a, those for the large plots 55 and 56 in Figures $2 b$ and $2 c$, respectively. The regression slopes (Table 2 ) are not statistically different from one another, and we have therefore combined the data from all KNP fires in regression calculations done separately with the data from each of the three laboratories participating in the KNP measurements (Table 2). Again, the regression parameters are not significantly different, which shows that no significant interlaboratory biases are present. Furthermore, the agreement between the NCAR data, which were obtained by GC/MS, and the MPIC measurements, which were made using electron capture and flame ionization detectors, demonstrates that no significant coelution problems interfered with the determination of $\mathrm{CH}_{3} \mathrm{Cl}$ by the less selective detectors.

The results from the two Drakensberg fires and the sugarcane fires are shown in Figures $3 a$ and $3 b$, respectively. Only two data points were available from the Drakensberg fire near Belfast, where grassland and native shrubland were burning. These two points suggest a substantially higher emission ratio $\Delta \mathrm{CH}_{3} \mathrm{Cl} / \Delta \mathrm{CO}$ than measured in all other fires, about $4 \times 10^{-3}$, but
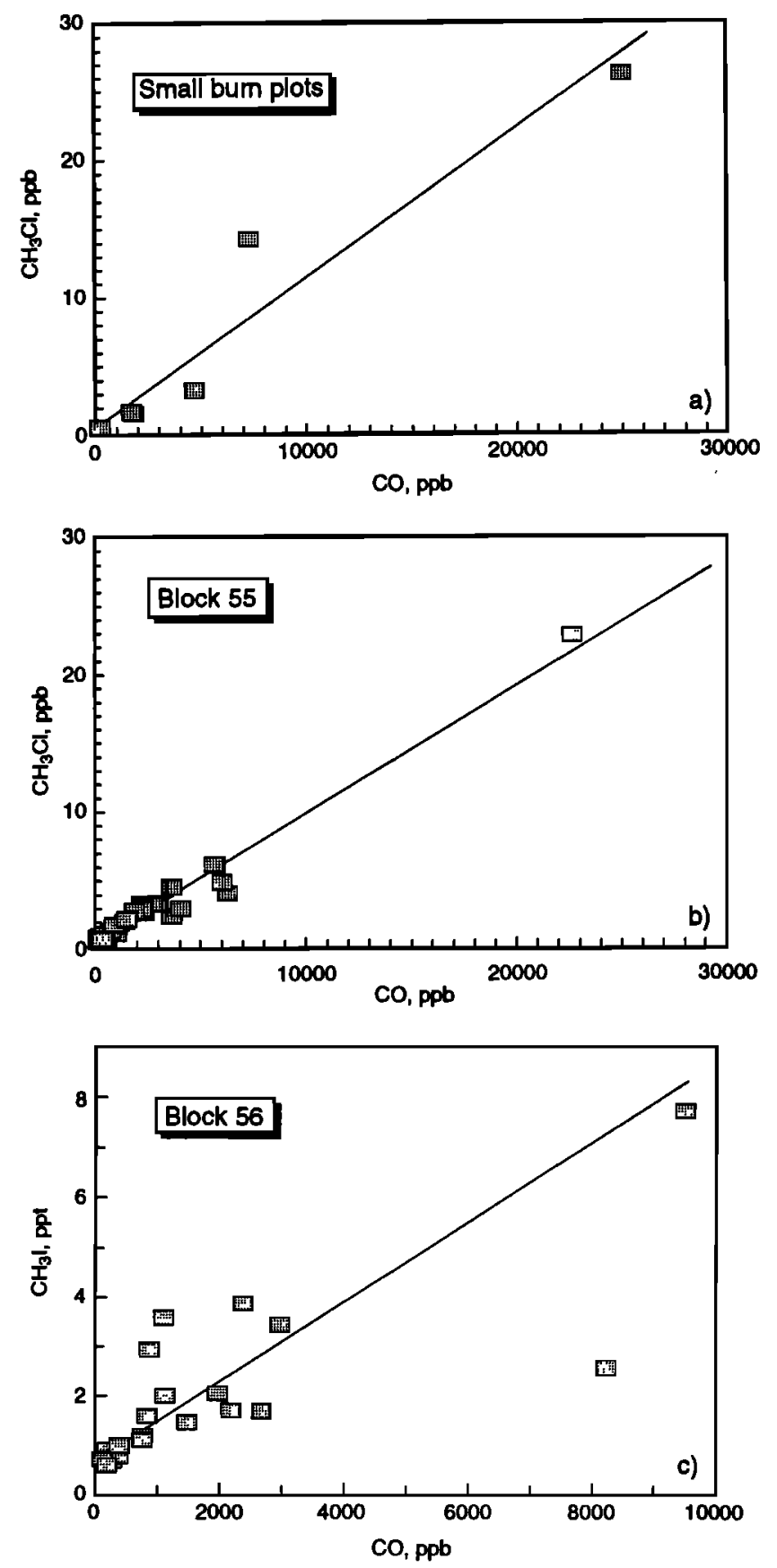

Figure 2. Methyl chloride concentrations in the samples collected from the smoke plumes of the Kruger Park experimental fires plotted against CO: (a) small plots; (b) large plot 55; (c) large plot 56. 
Table 2. Methyl Chloride Emission Ratios From the Savanna Fires Sampled During SAFARI-92

\begin{tabular}{lccccccc}
\hline Samples & $\begin{array}{c}\Delta \mathrm{CO} / \Delta \mathrm{CO}_{2}, \\
\mathrm{x} 10^{-3}\end{array}$ & $\begin{array}{c}\Delta \mathrm{CH}_{3} \mathrm{Cl} / \Delta \mathrm{CO}, \\
\mathbf{x} 10^{-3}\end{array}$ & $\mathrm{r}^{2}$ & $\mathrm{~N}$ & $\begin{array}{c}\Delta \mathrm{CH}_{3} \mathrm{Cl} / \Delta \mathrm{CO}_{2,} \\
\mathrm{xl}^{-6}\end{array}$ & $\mathrm{r}^{2}$ & $\mathrm{~N}$ \\
\hline KNP small plots & $36 \pm 11$ & $1.06 \pm 0.13$ & 0.93 & 6 & $\ldots$ & $\ldots$ & $\ldots$ \\
KNP large plot 56 & $33 \pm 3$ & $0.74 \pm 0.18$ & 0.82 & 22 & $32 \pm 8$ & 0.53 & 17 \\
KNP large plot 55 & $51 \pm 2$ & $0.94 \pm 0.03$ & 0.97 & 39 & $17 \pm 4$ & 0.41 & 39 \\
All Kruger Park fires & & & & & & & \\
$\quad$ MPIC-K data & $40 \pm 20$ & $0.98 \pm 0.04$ & 0.96 & 25 & $21 \pm 2$ & 0.81 & 23 \\
$\quad$ MPIC-P data & $48 \pm 3$ & $1.04 \pm 0.13$ & 0.83 & 14 & $53 \pm 3$ & 0.96 & 14 \\
$\quad$ NCAR data & $27 \pm 9$ & $1.01 \pm 0.06$ & 0.93 & 23 & $14 \pm 8$ & 0.19 & 14 \\
Drakensberg (Nelspruit) & $105 \pm 3$ & $0.94 \pm 0.07$ & 0.94 & 12 & $99 \pm 7$ & 0.94 & 15 \\
Sugarcane fires & $18 \pm 2$ & $1.05 \pm 0.14$ & 0.92 & 7 & $19 \pm 3$ & 0.77 & 10 \\
Regional background & $\ldots$ & $1.23 \pm 0.22$ & 0.24 & 95 & $\ldots$ & $\ldots$ & $\ldots$ \\
SAFARI-92, all data & $53 \pm 21$ & $0.95 \pm 0.01$ & 0.95 & 176 & $20 \pm 2$ & 0.42 & 173 \\
\hline
\end{tabular}

the small sample number does not permit a statistically valid regression calculation. The measurements from the Drakensberg fire near Nelspruit yield a regression slope statistically indistinguishable from the KNP results (Table 2). The single measurement in a plume from a small savanna fire in northwesterm Zambia also suggests a relatively high emission ratio $\left(5.3 \times 10^{-3}\right)$ if the samples taken before and after are used as ambient reference. Again, however, proper statistical analysis is not possible.
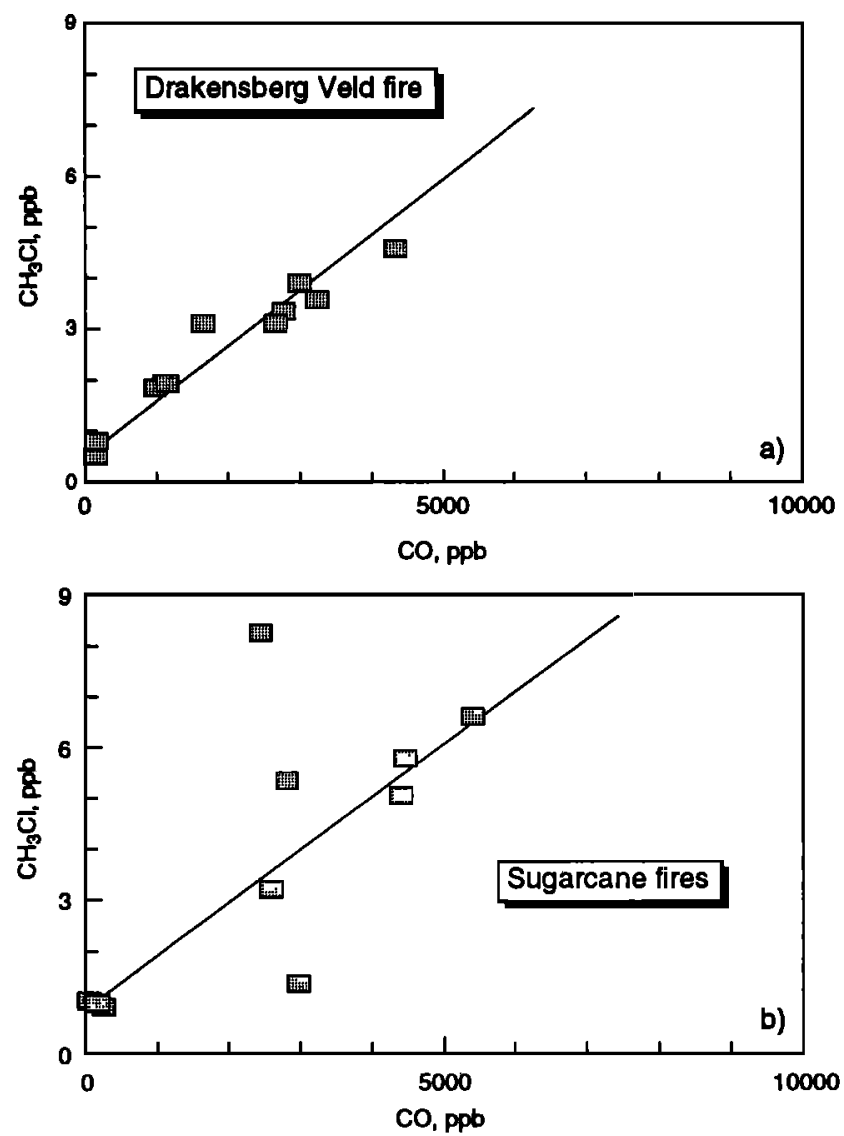

Figure 3. Methyl chloride concentrations in the samples collected from the smoke plumes of (a) the Drakensberg veld fire and (b) the sugarcane field fires plotted against $\mathrm{CO}$.
When the $\mathrm{CH}_{3} \mathrm{Cl}$ concentrations from the samples taken outside of smoke plumes during the regional survey flights are plotted against $\mathrm{CO}$, a more diffuse, but still highly significant correlation is observed $\left(r^{2}=0.24, N=113, \alpha<0.0005\right.$; Figure 4, Table 2). The regression slope is slightly higher than that measured in the plumes $(1.23 \pm 0.22) \times 10^{-3}$, but the difference is at the margin of statistical significance. These results are consistent, however, with the conclusion drawn from other trace gas and aerosol measurements taken during SAFARI-92, that the regional atmosphere over southern Africa was loaded with substantial amounts of biomass smoke [Andreae et al., 1994; Maenhaut et al., this issue; G. W. Harris et al., manuscript in preparation, 1995; R. Koppmann et al., manuscript in preparation, 1995]. The mean $\mathrm{CH}_{3} \mathrm{Cl}$ concentration in the ambient samples was $886 \pm 180 \mathrm{ppt}$ (mean and standard deviation; $\mathrm{N}=113$ ), well above the global mean value of about $600 \mathrm{ppt}$ [Koppmann et al., 1993; Rasmussen et al., 1980; Singh et al., 1983]. Similarly, the mean CO concentration of $166 \pm 59 \mathrm{ppb}$ was substantially greater than southern hemispheric "clean" air (about 50-80 ppb [Novelli et al., 1994]). The regional distribution of these trace gases is discussed in companion papers [G. W. Harris, manuscript in preparation, 1995; G. Helas, manuscript in preparation, 1995; R. Koppmann, manuscript in preparation, 1995].

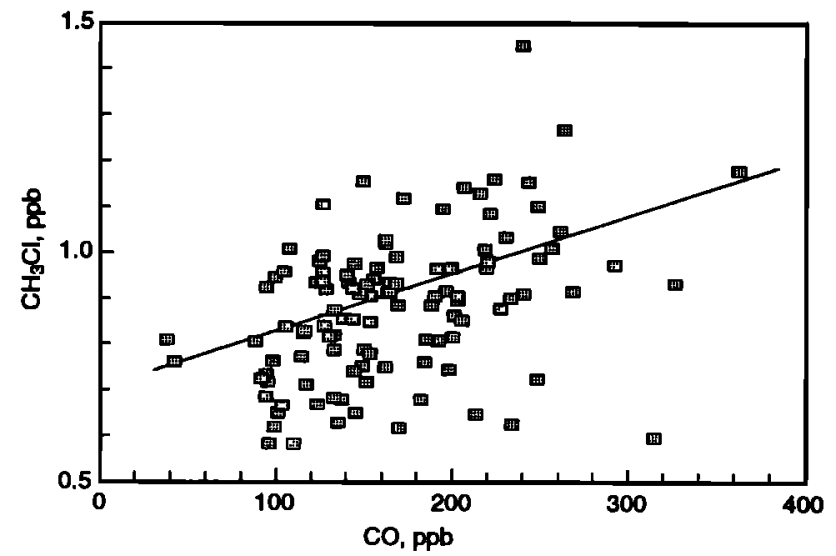

Figure 4. Methyl chloride concentrations in the samples collected during the regional survey flights over southern Africa plotted against $\mathrm{CO}$. 
The correlations between $\mathrm{CH}_{3} \mathrm{Cl}$ and $\mathrm{CO}_{2}$ are much more variable than between $\mathrm{CH}_{3} \mathrm{Cl}$ and $\mathrm{CO}$ (Table 2). When all data are used in the regression, a slope of $(33 \pm 3) \times 10^{-6}$ is obtained with a relatively low $r^{2}$ of 0.26 . Removing three obvious outliers (ground-based samples with extremely high $\mathrm{CO}$ concentration) reduces the emission ratio $\Delta \mathrm{CH}_{3} \mathrm{Cl} / \Delta \mathrm{CO}_{2}$ to $(20 \pm 2) \times 10^{-6}$, and improves $\mathrm{r}^{2}$ to 0.42 . The relatively weak overall correlation is due to significantly different emission ratios observed for the different fires. The most intensely flaming fires in the sugarcane fields and the KNP savanna had the lowest $\Delta \mathrm{CH}_{3} \mathrm{Cl} / \Delta \mathrm{CO}_{2}$ ratios (Table 2), while the Drakensberg forest fires had a $\Delta \mathrm{CH}_{3} \mathrm{Cl} / \Delta \mathrm{CO}_{2}$ ratio as high as $(99 \pm 7) \times 10^{-6}$. These differences reflect mostly the different $\Delta \mathrm{CO} / \Delta \mathrm{CO}_{2}$ emission ratios of the fires, which also are lowest in the sugarcane and savanna fires, and highest in the forest fires. The higher $\mathrm{CO}$ emission ratios in the forest fires are due to the higher proportion of smoldering combustion typical of woody fuel. Surprisingly, however, the $\Delta \mathrm{CH}_{3} \mathrm{Cl} / \Delta \mathrm{CO}_{2}$ and the $\triangle \mathrm{CO} / \Delta \mathrm{CO}_{2}$ emission ratios measured by the different groups for the KNP fires also differ from one another (Table 2), in spite of the good agreement between groups for the $\Delta \mathrm{CH}_{3} \mathrm{Cl} / \Delta \mathrm{CO}$ ratio. This must be due to different parts of the fires having been sampled by the different groups, and argues strongly for the use of $\Delta \mathrm{CH}_{3} \mathrm{Cl} / \Delta \mathrm{CO}$ emission ratios for making extrapolations from local measurements to regional and global $\mathrm{CH}_{3} \mathrm{Cl}$ emissions.

Our $\Delta \mathrm{CH}_{3} \mathrm{Cl} / \Delta \mathrm{CO}$ emission ratios (mean and range: $\left.0.95(0.74-1.23) \times 10^{-3}\right)$ agree well with the results obtained from laboratory fires by Lobert et al. [1991], who give a mean $\Delta \mathrm{CH}_{3} \mathrm{Cl} / \Delta \mathrm{CO}$ of $1.6 \times 10^{-3}$ with a range of $(0.180-4.37) \times 10^{-3}$ for a variety of fuels including savanna grass, hay, straw, and pine branches. Both our study and Lobert et al.'s gave $\Delta \mathrm{CH}_{3} \mathrm{Cl} / \Delta \mathrm{CO}$ emission ratios well above those published by Laursen et al. [1992], who found a mean and range of $0.16(0.06-0.40) \times 10^{-3}$ from forest fires in North America. Their highest values are from fires in California chaparral, their lowest emission ratios from fires in temperate conifer forests. Under constant combustion conditions, the amount of $\mathrm{CH}_{3} \mathrm{Cl}$ emitted from fires is controlled by the amount of chloride present in the fuel [Reinhardt, 1987]. Since $\mathrm{CH}_{3} \mathrm{Cl}$ is mainly produced during the smoldering phase, and $\mathrm{CO}$ is a specific tracer for this mode of combustion, it follows that $\Delta \mathrm{CH}_{3} \mathrm{Cl} / \Delta \mathrm{CO}$ is predominantly a function of the fuel halogen content. The high values of $\Delta \mathrm{CH}_{3} \mathrm{Cl} / \Delta \mathrm{CO}$ in smoke from savanna fires as compared to emissions from temperate forest fires are thus consistent with the high $\mathrm{Cl}$ content of savanna grasses relative to that of temperate forest biomass [McKenzie et al., 1996].

On the other hand, our emission ratios relative to $\mathrm{CO}_{2}$ (20(14-99) $\left.\times 10^{-6}\right)$ agree well with Laursen et al.'s $\left(12(6-21) \times 10^{-6}\right)$, and also with the results from a Colorado forest fire (23(4-57) $\left.\times 10^{-6}\right)$ published by Crutzen et al. [1979]. The emission ratios from southern Africa are somewhat lower than those of Rudolph et al. [1995], who obtained a mean $\Delta \mathrm{CH}_{3} \mathrm{Cl} / \Delta \mathrm{CO}_{2}$ of $43 \times 10^{-6}$ in smoke plumes from west African savanna fires. Lobert et al. [1991] did not give $\Delta \mathrm{CH}_{3} \mathrm{Cl} / \Delta \mathrm{CO}_{2}$ ratios, but from their $\Delta \mathrm{CH}_{3} \mathrm{Cl} / \Delta \mathrm{CO}$ and $\Delta \mathrm{CO} / \Delta \mathrm{CO}_{2}$ ratios a mean $\Delta \mathrm{CH}_{3} \mathrm{Cl} / \Delta \mathrm{CO}_{2}$ of $120 \times 10^{-6}$ can be estimated. This value and Rasmussen et al.'s [1980] value of $120 \times 10^{-6}$ from laboratory burns of various fuels are well above our savanna ratio of about $20 \times 10^{-6}$. On the other hand, our measurements from the Drakensberg forest fire gave a ratio $\left(99 \times 10^{-6}\right)$ similar to Rasmussen et al.'s [1980]. This ratio is considerably higher than emission ratios from temperate forests [Crutzen et al., 1979; Laursen et al., 1992] and our own boreal forest measurements
(Siberia: $61 \times 10^{-6}$, Finland: $48 \times 10^{-6} ;$ M.O. Andreae, unpublished data, 1994). The highest mean $\Delta \mathrm{CH}_{3} \mathrm{Cl} / \Delta \mathrm{CO}_{2}\left(290 \times 10^{-6}\right)$ ratio was reported by $S$. Tassios and D. R. Packham [1985] from fires in eucalypt forests in Western Australia. It appears thus that tropical and subtropical forest fires emit more $\mathrm{CH}_{3} \mathrm{Cl}$ per amount of $\mathrm{CO}_{2}$ released (or biomass burned) than savanna fires, in spite of the higher $\mathrm{Cl}$ content of the savanna vegetation. This may be the result of the much larger fraction of smoldering combustion in forest fires compared to savanna fires.

\section{Methyl Bromide}

Methyl bromide and methyl iodide measurements are available only for the Kruger Park fires. The $\mathrm{CH}_{3} \mathrm{Br}$ concentrations in the smoke samples from the small and the large fire plots are highly correlated with the corresponding $\mathrm{CH}_{3} \mathrm{Cl}$ data, and when plotted together, all appear to be part of a common regression line (Figure 5a). The same applies to the relationship between $\mathrm{CH}_{3} \mathrm{Br}$ and $\mathrm{CO}$ (Figure $5 \mathrm{~b}$ ). When regression calculations are performed separately for the different plots, some differences emerge (Table 3 ). The closest correlations are found for the samples from the large plot 55 , where $r^{2}$ is 0.97 for $\mathrm{CH}_{3} \mathrm{Br}$ versus $\mathrm{CO}$ and 0.99 for $\mathrm{CH}_{3} \mathrm{Br}$ versus $\mathrm{CH}_{3} \mathrm{Cl}$ and the regression slopes (emission ratios) are $9.5 \times 10^{-3}$ and $9.6 \times 10^{-3}$, respectively. The data from the small fires give somewhat lower emission ratios, $8.1 \times 10^{-3}$ and $7.7 \times 10^{-3}$, respectively. The difference in the emission ratios relative to $\mathrm{CO}$ is, however, not statistically significant. The measurements from the large plot 56 show the largest scatter and the lowest emission ratios. When all data points are used in the regression, the $\Delta \mathrm{CH}_{3} \mathrm{Br} / \Delta \mathrm{CO}$ slope is only $(3.9 \pm 0.5) \times 10^{-3}$; when the data point with the highest $\mathrm{CO}$ concentration is removed, the ratio increases to $(6.5 \pm 2.0) \times 10^{-3}$, while $r^{2}$ decreases from 0.91 to 0.72 . This sample came from a small heading fire separate from the main fire and may have had anomalous fuel composition or combustion conditions. Using the data from all SAFARI-92 fires, we obtain a $\Delta \mathrm{CH}_{3} \mathrm{Br} / \Delta \mathrm{CO}$ ratio of $(8.3 \pm 0.4) \times 10^{-3}$, which is in close agreement with the data by Rowland et al. [1994] who measured a ratio of $9 \times 10^{-3}$ in smoke plumes from savanna and tropical forest fires in Brazil.

The scatterplot of $\mathrm{CH}_{3} \mathrm{Br}$ versus $\mathrm{CO}_{2}$ (Figure $5 \mathrm{c}$ ) shows the same poor correlation as had already been observed for $\mathrm{CH}_{3} \mathrm{Cl}$ versus $\mathrm{CO}_{2}$. The three points with high very $\mathrm{CO}$ concentrations have been omitted from this plot and from the regression analysis. This is justified, since the kind of smoldering-dominated smoke represented by these samples contributes relatively little to the total $\mathrm{CO}_{2}$ output of the fire. Therefore, their inclusion would result in an upward bias of the $\mathrm{CO}_{2}$-based emission ratios. Analyzed for the individual fires, there is substantial apparent variation in the $\Delta \mathrm{CH}_{3} \mathrm{Br} / \Delta \mathrm{CO}_{2}$ emission ratios, but in view of the large standard errors associated with the small sample numbers and low regression coefficients, these variations are not statistically significant. The $\Delta \mathrm{CH}_{3} \mathrm{Br} / \Delta \mathrm{CO}_{2}$ emission ratios measured by Mano [1994] in smoke from a boreal forest fire also show great variability, depending on whether the samples were collected from flaming combustion $\left(0.12 \times 10^{-6}\right)$ or from smoldering combustion (up to $3.2 \times 10^{-6}$ ).

\section{Methyl Iodide}

The scatterplots for $\mathrm{CH}_{3} \mathrm{I}$ versus $\mathrm{CH}_{3} \mathrm{Cl}, \mathrm{CO}$, and $\mathrm{CO}_{2}$ are shown in Figures 6abc. Again, good correlations are seen for $\mathrm{CH}_{3} \mathrm{I}$ is $\mathrm{CH}_{3} \mathrm{Cl}$ and $\mathrm{CO}$, and a much poorer correlation for $\mathrm{CH}_{3} \mathrm{I}$ versus $\mathrm{CO}_{2}$. The emission factor $\Delta \mathrm{CH}_{3} \mathrm{I} / \Delta \mathrm{CH}_{3} \mathrm{Br}$ is highly dependent on the inclusion of one point with very high $\mathrm{CH}_{3} \mathrm{I}$ 

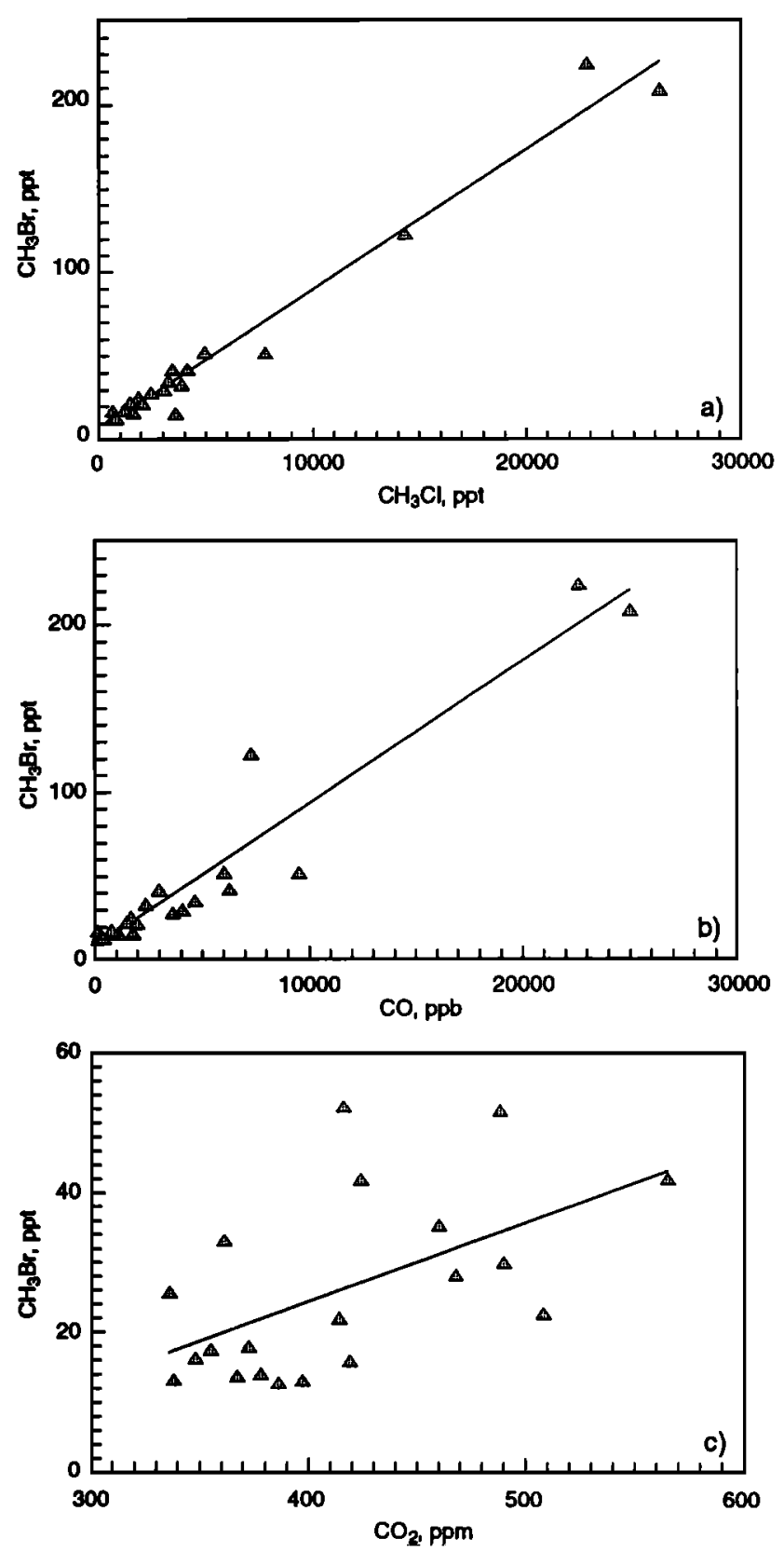

Figure 5. Methyl bromide concentrations in samples from the Kruger Park fires plotted against (a) methyl chloride, (b) $\mathrm{CO}$, and (c) $\mathrm{CO}_{2}$.

concentration: Upon removal of this point, the slope decreases from $(4.5 \pm 0.6) \times 10^{-3}\left(r^{2}=0.71\right)$ to $(2.6 \pm 0.2) \times 10^{-3}\left(r^{2}=0.83\right)$. This sample was collected on the ground and may represent unusual fuel composition or burning characteristics. It falls far from the trend line also in the scatterplots relative to $\mathrm{CO}$ and $\mathrm{CO}_{2}$. As it is outside of the $95 \%$ confidence limits of the regression equation, it is rejected as an outlier, and the emission ratios in Table 4 are calculated after this value has been excluded.

\section{Fuel Halogen Content and Halogen Species Volatilization}

We determined the halogen element concentrations in fuel samples from the two large blocks and three of the small fire plots studied at KNP (Table 5). The average $\mathrm{Cl}$ and $\mathrm{Br}$ concentrations in the fuel, $1260 \pm 310$ and $7.0 \pm 1.6 \mathrm{mg} \mathrm{kg}^{-1}$, are somewhat higher than the values measured on miombo savanna vegetation from Zambia by McKenzie et al. [1996]. After weighting for the contributions of the different fuel components to the amount of fuel burned, their averages are $650 \mathrm{mg} \mathrm{Cl} \mathrm{kg}^{-1}$ and $4.0 \mathrm{mg} \mathrm{Br} \mathrm{kg}{ }^{-1}$. Some of this difference is due to the different fuel mixture at the two sites: At KNP, the grass fraction dominates and the fuel composition is essentially that of the grass component, whereas at the miombo site a large litter fraction with lower halogen content is present. The grass fraction at the miombo site $\left(1000 \mathrm{mg} \mathrm{Cl} \mathrm{kg}^{-1}\right.$ and $4.8 \mathrm{mg} \mathrm{Br} \mathrm{kg}^{-1}$ [McKenzie et al., 1996]) is not significantly different from the KNP fuel. No iodine data are available in the literature for comparison.

The halogen concentrations in the savanna fuels are considerably higher than those in most forest fuels, especially in forest fuels from temperate regions [McKenzie et al, , 1996]. This helps to explain why the $\Delta \mathrm{CH}_{3} \mathrm{Cl} / \Delta \mathrm{CO}$ values from savanna fires tend to be higher than those from forest fires. A generally high chloride content in savanna vegetation is also suggested by the very high levels of chloride in aerosols and precipitation influenced by biomass burning in both southern and west Africa [Lacaux et al., 1991; Lefeivre, 1993; M. O. Andreae et al., manuscript in preparation, 1995].

The molar ratio $\mathrm{Cl} / \mathrm{Br}$ in the $\mathrm{KNP}$ fuel is $406: 1$, somewhat higher than the ratio measured by McKenzie et al. [1996] in Zambia (366:1). At both savanna sites, the $\mathrm{Cl} / \mathrm{Br}$ ratios are considerably higher than in forest vegetation from tropical and temperate regions, where $M c K e n z i e$ et al. [1996] found values near 100:1. This may explain the higher $\mathrm{CH}_{3} \mathrm{Cl} / \mathrm{CH}_{3} \mathrm{Br}$ ratio in the savanna smoke (120:1) as compared to the smoke from boreal forest fires in Siberia (53:1) [Mano and Andreae, 1994] and Finland (21:1) (M.O. Andreae, unpublished data, 1994).

The amount of halogens released by the fires can be calculated from the halogen loadings in the fuel minus the halogens remaining in the unburned residue and ash. When this value is divided by the amount of halogen in the prefire fuel, the fraction emitted in the fire is obtained (fuel and residue loadings from Kuhlbusch et al. [this issue] were used for these calculations). This value is close to $80 \%$ for all three halogen elements analyzed (Table 6). The emission fraction relative to the fuel burned can be obtained from these numbers by dividing by 0.88 , the fraction of the prefire fuel consumed in the fire. This

Table 3. Methyl Bromide Emission Ratios to $\mathrm{CH}_{3} \mathrm{Cl}$, $\mathrm{CO}$, and $\mathrm{CO}_{2}$ From the Kruger Park Savanna Fires

\begin{tabular}{lccccccr}
\hline & $\begin{array}{c}\Delta \mathrm{CH}_{3} \mathrm{Br} / \Delta \mathrm{CH}_{3} \mathrm{Cl}, \\
\text { Samples }\end{array}$ & $\mathrm{x}^{-3}$ & $\begin{array}{c}\Delta \mathrm{CH}_{3} \mathrm{Br} / \Delta \mathrm{CO}, \\
\mathrm{x} 10^{-6}\end{array}$ & $\mathrm{r}^{2}$ & $\begin{array}{c}\Delta \mathrm{CH}_{3} \mathrm{Br} / \Delta \mathrm{CO}_{2}, \\
\mathrm{x}^{2} 0^{-6}\end{array}$ & $\mathrm{r}^{2}$ & $\mathrm{~N}$ \\
\hline Small plots & $7.7 \pm 0.1$ & 0.99 & $8.1 \pm 1.1$ & 0.91 & $0.48 \pm 0.38$ & 0.44 & 7 \\
Large plot 56 & $5.2 \pm 0.3$ & 0.99 & $3.9 \pm 0.5$ & 0.91 & $0.20 \pm 0.11$ & 0.46 & 6 \\
Large plot 55 & $9.6 \pm 0.1$ & 0.99 & $9.5 \pm 0.6$ & 0.97 & $0.07 \pm 0.07$ & 0.14 & 8 \\
All KNP fires & $8.3 \pm 0.3$ & 0.97 & $8.3 \pm 0.4$ & 0.95 & $0.11 \pm 0.04$ & 0.30 & 23 \\
\hline
\end{tabular}



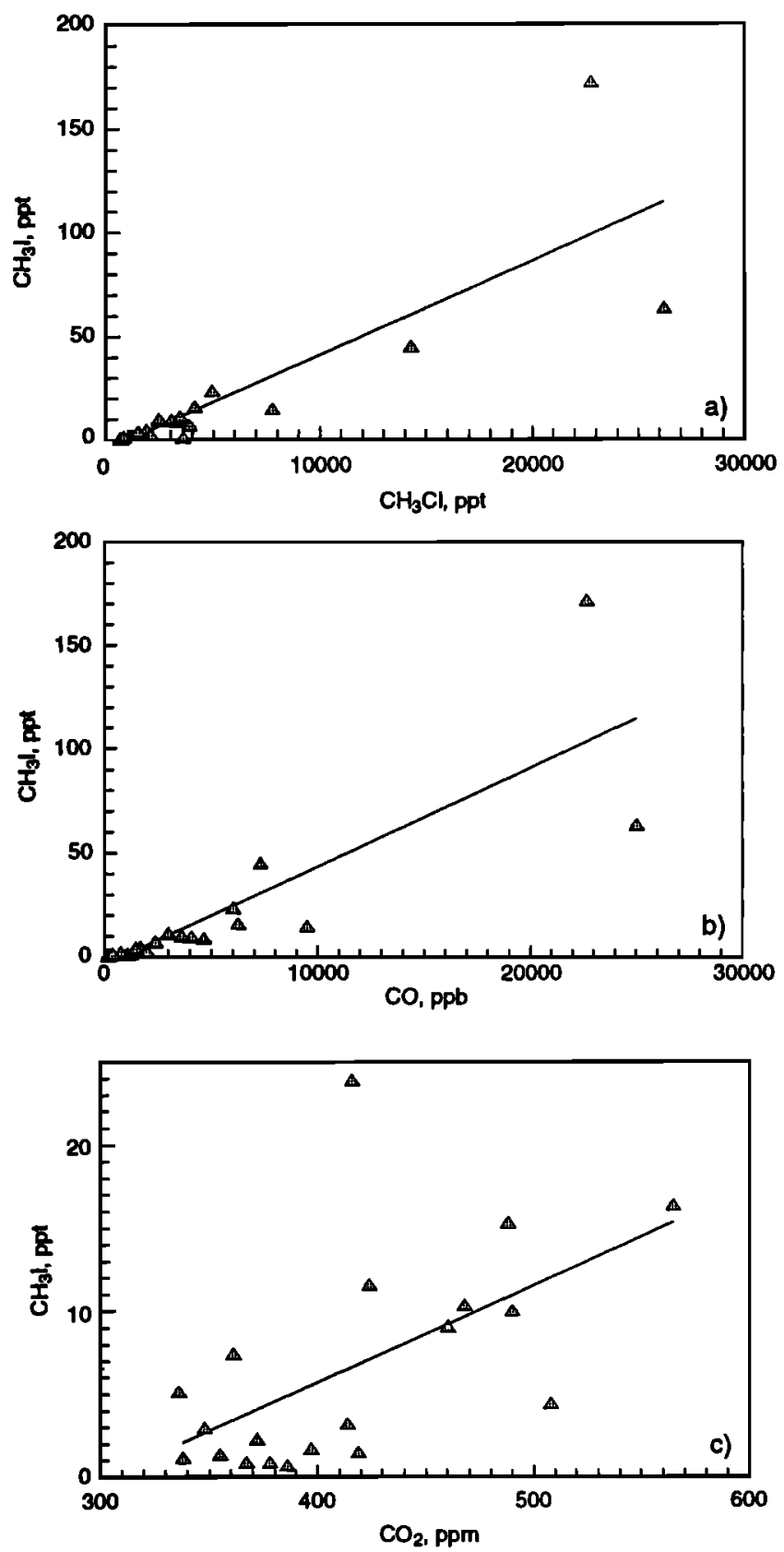

Figure 6. Methyl iodide concentrations in samples from the Kruger Park fires plotted against (a) methyl chloride, (b) $\mathrm{CO}$, and (c) $\mathrm{CO}_{2}$.

shows that some $90 \%$ of the halogen elements present in the fuel burned were actually released to the atmosphere during combustion. The ratio of total halogen to $\mathrm{CO}_{2}$ emitted by the fire $\left(\mathrm{X}_{\text {total }} / \mathrm{CO}_{2}\right.$ in Table 6$)$ as calculated from fuel and residue analysis can be compared to the emission ratios of halogen and methyl halide species measured in the smoke. The emission ratios for the halide ions determined in the Kruger Park fires are in reasonable agreement with the ratios predicted from the fuel/residue budget. The chloride emission ratio $\left((1100 \pm 700) \times 10^{-6}\right)$ given in Table 6 is from Andreae [1996] and actually exceeds the amount of chlorine released by combustion; with the aerosol composition data of Maenhaut et al. [this issue] a chloride emission ratio of $510 \times 10^{-6}$ and a fraction $\mathrm{Cl}_{\text {inorg }} / \mathrm{Cl}_{\text {total }}$ of $56 \%$ would be obtained. These differences are probably mostly due to sampling variability, as the high standard deviation of Andreae's [1996] value shows as well. These results suggest that most of the fuel halogen content is released either directly as halide particles or as hydrogen halides which rapidly combine with alkaline substances in the aerosol or with gaseous ammonia to give halide particles.

In Table 6 we also compare the methyl halide emission ratios with the total halogen element emission. For $\mathrm{CH}_{3} \mathrm{Cl}$, the methylated species accounts for $3.0 \pm 1.9 \%$ of the total chlorine emitted. This fraction increases to $5.0 \pm 2.6 \%$ for bromine and to $38 \pm 25 \%$ for iodine. In the case of iodine, this fraction appears very large and may reflect measurement uncertainties and sampling variability. Nevertheless, our results suggest that a significant fraction of the fuel halogen content is methylated in the combustion process and that this fraction increases in the sequence $\mathrm{Cl}<\mathrm{Br}<\mathrm{I}$.

\section{Methyl Halide Emissions From Biomass Burning}

In Table 7 we present the results of attempts to estimate the flux of the methyl halides from savanna fires and from all types of biomass burning worldwide. No formal assessment of the uncertainties involved in these calculations can be given, since the data required for an error analysis are not available. A rough estimate of uncertainty in the source estimates can be gained from the considerations that the pyrogenic emissions of $\mathrm{CO}$ and $\mathrm{CO}_{2}$ (which are used in the extrapolation) are known to within about $\pm 50 \%$ and that uncertainties related to the emission ratios for the methyl halides are at least a factor of 2 . The overall uncertainty is thus probably about a factor of 3 , probably even larger in the case of $\mathrm{CH}_{3} \mathrm{Br}$ and $\mathrm{CH}_{3} \mathrm{I}$.

For our calculations, we assume that the data from SAFARI-92 can be applied to savannas in general and use the estimate of $1660 \mathrm{Tg} \mathrm{C}\left(\mathrm{CO}_{2}\right)$ emitted annually from savanna fires proposed by Andreae [1993]. Using a mean $\Delta \mathrm{CO} / \Delta \mathrm{CO}_{2}$ of 0.063 for savanna fires [Lacaux et al., 1995; Ward et al., 1992; Andreae, 1995; G.W. Harris et al., manuscript in preparation, 1996] and the mean emission ratios from SAFARI-92, we obtain an annual emission of $420 \mathrm{Gg} \mathrm{CH}_{3} \mathrm{Cl}$, or about $10-15 \%$ of the global $\mathrm{CH}_{3} \mathrm{Cl}$ source. When the calculation is based on $\mathrm{CO}_{2}$, a much lower flux of $130 \mathrm{Gg} \mathrm{yr}^{-1}$ is obtained, but as we have argued above, the emission ratio relative to $\mathrm{CO}_{2}$ is much less reliable than the CO-based one, which should be used

Table 4. Methyl Iodide Emission Ratios to $\mathrm{CH}_{3} \mathrm{Cl}, \mathrm{CO}$, and $\mathrm{CO}_{2}$ From the Kruger Park Savanna Fires

\begin{tabular}{lccccccr}
\hline Samples & $\begin{array}{c}\Delta \mathrm{CH}_{3} \mathrm{I} / \Delta \mathrm{CH}_{3} \mathrm{Cl}, \\
\mathrm{x} 10^{-3}\end{array}$ & $\mathrm{r}^{2}$ & $\begin{array}{c}\Delta \mathrm{CH}_{3} \mathrm{I} / \Delta \mathrm{CO}, \\
\mathrm{x} 10^{-6}\end{array}$ & $\mathrm{r}^{2}$ & $\begin{array}{c}\Delta \mathrm{CH}_{3} \mathrm{I} / \Delta \mathrm{CO}_{2,}, \\
\mathbf{x 1 0}^{-6}\end{array}$ & $\mathrm{r}^{2}$ & $\mathrm{~N}$ \\
\hline KNP small plots & $2.5 \pm 0.2$ & 0.98 & $2.6 \pm 0.6$ & 0.81 & $0.28 \pm 0.20$ & 0.40 & 6 \\
Large plot 56 & $2.0 \pm 0.4$ & 0.85 & $1.5 \pm 0.2$ & 0.94 & $0.08 \pm 0.04$ & 0.49 & 8 \\
Large plot 55 & $4.8 \pm 0.4$ & 0.96 & $3.1 \pm 0.5$ & 0.88 & $0.04 \pm 0.04$ & 0.12 & 6 \\
All KNP fires & $2.6 \pm 0.2$ & 0.93 & $2.6 \pm 0.3$ & 0.83 & $0.09 \pm 0.05$ & 0.14 & 23 \\
\hline
\end{tabular}


Table 5. Halogen Element Content in the Savanna Fire Fuels and Residues From Kruger Park, and Fraction of Element Emitted to the Atmosphere During the Fires on the Large Blocks

\begin{tabular}{lccc}
\hline & Chlorine & Bromine & Iodine \\
\hline & Concentration in Fuel, $\mathrm{g} \mathrm{kg}^{-1}$ & & \\
Plot Napi \#3 & $1785 \pm 70$ & $9.8 \pm 0.3$ & $1.17 \pm 0.19$ \\
Plot Shabeni \#5 & $1530 \pm 90$ & $8.7 \pm 0.4$ & $1.13 \pm 0.24$ \\
Plot Kabeni Extra & $1160 \pm 340$ & $6.7 \pm 0.5$ & $1.10 \pm 0.10$ \\
Large block 55 & $950 \pm 120$ & $6.0 \pm 0.4$ & $1.64 \pm 0.16$ \\
Large block 56 & $1190 \pm 130$ & $5.4 \pm 0.6$ & $1.23 \pm 0.30$ \\
& $1260 \pm 310$ & $7.0 \pm 1.6$ & $1.28 \pm 0.30$ \\
& Average & & \\
Prefire fuel halogen loading,g ha ${ }^{-1}$ & 9530 & 60 & 16 \\
Postfire halogen loading, g ha ${ }^{-1}$ & 1180 & 6 & 4 \\
Fraction emitted, \% & $88 \%$ & $90 \%$ & $76 \%$ \\
& Block 56 & & \\
Prefire fuel halogen loading, g ha-1 & 6230 & 28 & 6 \\
Postfire halogen loading, g ha-1 & 1350 & 8 & $\mathrm{ND}$ \\
Fraction emitted, \% & $78 \%$ & $71 \%$ & \\
& & & \\
Fraction emitted, \% & Average, Blocks 55 and 56 & $81 \%$ & $76 \%$ \\
\hline
\end{tabular}

ND denotes not determined.

preferentially. These emissions can be compared to the total worldwide $\mathrm{CH}_{3} \mathrm{Cl}$ emissions from biomass burning, which include forest fires, agricultural burning, domestic biomass fuel use, etc. For this calculation, we use global pyrogenic $\mathrm{CO}$ and $\mathrm{CO}_{2}$ emission estimates $\left(13,200 \mathrm{Tg} \mathrm{CO}_{2} \mathrm{yr}^{-1}\left(3600 \mathrm{Tg} \mathrm{C}\left(\mathrm{CO}_{2}\right)\right.\right.$ $\left.\mathrm{yr}^{-1}\right)$ and $680 \mathrm{Tg} \mathrm{CO} \mathrm{yr}^{-1}\left(290 \mathrm{Tg} \mathrm{C}(\mathrm{CO}) \mathrm{yr}^{-1}\right)$ [ Andreae, 1993]) and the mean emission ratios calculated from the data in this study and from literature data cited above. With the $\mathrm{CO}$ and the $\mathrm{CO}_{2}$-based emission ratios, a global pyrogenic $\mathrm{CH}_{3} \mathrm{Cl}$ emission of approximately 1100 or $1500 \mathrm{Gg} \mathrm{yr}{ }^{-1}$, respectively, is obtained, corresponding to about one third to one half of the total $\mathrm{CH}_{3} \mathrm{Cl}$ source strength. This value is consistent with the range of emission estimates for $\mathrm{CH}_{3} \mathrm{Cl}$ from biomass burning (650-2600 $\left.\mathrm{Gg} \mathrm{yr}^{-1}\right)$ proposed by Andreae [1993].

Methyl bromide emissions can be estimated based on $\mathrm{CO}$, $\mathrm{CO}_{2}$, or $\mathrm{CH}_{3} \mathrm{Cl}$ as reference species. The same $\mathrm{CO}$ and $\mathrm{CO}_{2}$ fluxes are used as for the $\mathrm{CH}_{3} \mathrm{Cl}$ flux calculations, and for the estimate based on $\mathrm{CH}_{3} \mathrm{Cl}$, we use the pyrogenic $\mathrm{CH}_{3} \mathrm{Cl}$ fluxes of 420 and $1300 \mathrm{Gg} \mathrm{yr}^{-1}$ derived in Table 7. For the estimates of $\mathrm{CH}_{3} \mathrm{Br}$ emission from all biomass burning, we took the mean emission factors from Mano and Andreae [1994]. Again, the $\mathrm{CO}_{2}$-based flux from the savanna fires comes out relatively low, while the other estimates agree well with each other, suggesting an emission of about $7 \mathrm{Gg} \mathrm{CH}_{3} \mathrm{Br} \mathrm{yr} \mathrm{r}^{-1}$ from savanna fires and about $20 \mathrm{Gg} \mathrm{yr}^{-1}$ from all biomass burning. The latter value corresponds to about $20 \%$ of the total $\mathrm{CH}_{3} \mathrm{Br}$ emission from all sources. The $\mathrm{CH}_{3} \mathrm{I}$ emission estimates are obtained in the same way as those for $\mathrm{CH}_{3} \mathrm{Br}$, only that in the absence of literature data on pyrogenic $\mathrm{CH}_{3} \mathrm{I}$ emission ratios from other types of fires we had to apply the SAFARI-92 values to all types of biomass burning. Clearly, the contribution of biomass burning to the tropospheric $\mathrm{CH}_{3} \mathrm{I}$ budget $\left(<10 \mathrm{Tg} \mathrm{yr}^{-1}\right)$ is trivial compared to the oceanic source of about $300 \mathrm{Tg} \mathrm{yr}^{-1}$ [Singh et al., 1983].

\section{Conclusions}

We found that methyl chloride, bromide, and iodide were emitted from the savanna fires investigated during SAFARI-92 in southern Africa. The concentrations of the methyl halides in smoke samples were highly correlated among each other; they were also strongly correlated with carbon monoxide concentrations. The correlation slopes (which are equivalent to emission ratios) are highly consistent between fires for most of the trace gas species pairs. The correlation between

Table 6. Fuel Elemental Composition, Volatilization Fraction, and Emission Ratios for Halogen Species

\begin{tabular}{|c|c|c|c|c|c|c|c|}
\hline Element & $\begin{array}{c}\text { Element Content } \\
\text { in Fuel, } \\
\text { mg kg }\end{array}$ & $\begin{array}{l}\text { Fraction } \\
\text { Emitted, } \\
\quad \%\end{array}$ & $\begin{array}{c}\mathrm{X}_{\text {total }} / \mathrm{CO}_{2} \\
\text { Emitted } \\
\mu \mathrm{mol} / \mathrm{mol}\end{array}$ & $\begin{array}{c}\Delta \mathrm{X}_{\text {inorg }} / \Delta \mathrm{CO}_{2} \\
\text { in Smoke } \\
\mu \mathrm{mol} / \mathrm{mol}\end{array}$ & $\mathrm{X}_{\text {inorg }} \underset{\%}{ } / \mathrm{X}_{\text {total }}$ & $\begin{array}{c}\Delta \mathrm{CH}_{3} \mathrm{X} / \Delta \mathrm{CO}_{2} \\
\text { in Smoke } \\
\mu \mathrm{mol} / \mathrm{mol}\end{array}$ & $\underset{\%}{\mathrm{CH}_{3} \mathrm{X} / \mathrm{X}}$ \\
\hline Carbon & $480,000 \pm 14,000$ & $88 \%$ & $\ldots$ & $\cdots$ & & & $\ldots$ \\
\hline Chlorine & $1260 \pm 310$ & $83 \%$ & $910 \pm 350$ & $1100 \pm 700$ & $121 \%$ & $27 \pm 14$ & $3.0 \%$ \\
\hline Bromine & $7.0 \pm 1.6$ & $81 \%$ & $2.2 \pm 0.8$ & $1.7^{\mathrm{b}}$ & $77 \%$ & $0.11 \pm 0.04$ & $5.0 \%$ \\
\hline Iodine & $1.3 \pm 0.3$ & $76 \%$ & $0.24 \pm 0.09$ & $0.17^{b}$ & $71 \%$ & $0.09 \pm 0.05$ & $38 \%$ \\
\hline
\end{tabular}

\footnotetext{
${ }^{\text {a Mean }} \Delta \mathrm{CH}_{3} \mathrm{X} / \Delta \mathrm{CO}_{2}$ emission ratios for the KNP fires.

${ }^{b}$ Based on smoke aerosol composition data from Maenhaut et al. [this issue].
} 
Table 7. Methyl Halide Emissions From Savanna Fires and All Types of Biomass Burning Worldwide

\begin{tabular}{|c|c|c|c|c|c|c|}
\hline Species & $\begin{array}{l}\text { SAFARI-92 } \\
\text { Emission } \\
\text { Ratio, } x 10^{-6}\end{array}$ & $\begin{array}{l}\text { Reference } \\
\text { Species } \\
\text { Flux, Tg yr }{ }^{-1}\end{array}$ & $\begin{array}{l}\text { All Savanna } \\
\text { Fire Emissions, } \\
\mathrm{Gg} \mathrm{yr}^{-1}\end{array}$ & $\begin{array}{c}\text { Global Mean } \\
\text { Emission } \\
\text { Ratio }^{2}, \times 10^{-6}\end{array}$ & $\begin{array}{l}\text { Reference } \\
\text { Species } \\
\text { Flux, Tg yr }{ }^{-1}\end{array}$ & $\begin{array}{c}\text { All Biomass } \\
\text { Burning, } \\
\mathrm{Gg} \mathrm{yr}^{-1}\end{array}$ \\
\hline \multicolumn{7}{|l|}{ Methyl chloride } \\
\hline$\Delta \mathrm{CH}_{3} \mathrm{Cl} / \Delta \mathrm{CO}$ & 950 & 240 & 410 & 900 & 680 & 1100 \\
\hline$\Delta \mathrm{CH}_{3} \mathrm{Cl} / \Delta \mathrm{CO}_{2}$ & 20 & 6090 & 140 & 100 & 13,200 & 1510 \\
\hline \multicolumn{7}{|l|}{ Methyl bromide } \\
\hline$\Delta \mathrm{CH}_{3} \mathrm{Br} / \Delta \mathrm{CO}$ & 8.3 & 240 & 6.8 & 8.3 & 680 & 19 \\
\hline$\Delta \mathrm{CH}_{3} \mathrm{Br} / \Delta \mathrm{CH}_{3} \mathrm{Cl}$ & 8300 & 0.41 & 6.4 & 8500 & 1.3 & 21 \\
\hline$\Delta \mathrm{CH}_{3} \mathrm{Br} / \Delta \mathrm{CO}_{2}$ & 0.11 & 6090 & 1.4 & 0.85 & 13,200 & 24 \\
\hline \multicolumn{7}{|l|}{ Methyl iodide } \\
\hline$\Delta \mathrm{CH}_{3} \mathrm{I} / \Delta \mathrm{CO}$ & 2.6 & 240 & 2.8 & 2.6 & 680 & 8.0 \\
\hline$\Delta \mathrm{CH}_{3} \mathrm{I} / \Delta \mathrm{CH}_{3} \mathrm{Cl}$ & 2600 & 0.41 & 2.7 & 2600 & 1.3 & 8.5 \\
\hline$\Delta \mathrm{CH}_{3} \mathrm{I} / \Delta \mathrm{CO}_{2}$ & 0.09 & 6090 & 1.6 & 0.09 & 13,200 & 3.4 \\
\hline
\end{tabular}

a The mean emission ratios for all biomass burning are based on data from this study and on the papers by Crutzen et al. [1979], Laursen et al. [1992], Lobert et al. [1991], Manø and Andreae [1994], Rasmussen et al. [1980], Rudolph et al. [1994], and Tassios and Packham [1985].

the methyl halides and $\mathrm{CO}_{2}$ in the smoke samples is much poorer and fluctuates over a wide range from one fire to another. This reflects the fact that the methyl halides and $\mathrm{CO}$ are emitted predominantly during smoldering combustion. Most of the halogen content of the fuel is released as halide species during combustion. But, especially in the smoldering stage, a significant fraction of the fuel halogen content is emitted in the form of methylated species. As a result, the overall methylhalide emission ratios are dependent both on the halide content of the fuel and on the proportion of flaming versus smoldering combustion in the fires.

The mean $\mathrm{CH}_{3} \mathrm{Cl}$ emission ratio to $\mathrm{CO}_{2}\left(19 \times 10^{-6}\right)$ observed during SAFARI-92 is at the low end of the range of published values $\left((12-320) \times 10^{-6}\right)$, while the mean emission ratio to $\mathrm{CO}$ is close to the average value reported in the literature $\left(-900 \times 10^{-6}\right)$. This can be explained by the high fraction of flaming versus smoldering combustion in the savanna fires, in conjunction with the high halogen content of the savanna vegetation. On the basis of these emission ratios, we estimate that the annual emission of $\mathrm{CH}_{3} \mathrm{Cl}$ from savanna fires amounts to about $420 \mathrm{Gg} \mathrm{yr}^{-1}$, about one third of the total pyrogenic emission of $1100-1500 \mathrm{Gg} \mathrm{CH}_{3} \mathrm{Cl} \mathrm{yr}^{-1}$, and about $12 \%$ of the total source flux of $3400 \mathrm{Gg} \mathrm{CH}_{3} \mathrm{Cl} \mathrm{yr}{ }^{-1}$. This pyrogenic source estimate is subject to an uncertainty of at least a factor of 2-3; further studies, especially in tropical deforestation fires, are required to reduce this uncertainty.

The emission ratios for $\mathrm{CH}_{3} \mathrm{Br}$ from savanna fires are also relatively low compared to forest fires, and savanna fires therefore make only a modest contribution (about $7 \mathrm{Gg} \mathrm{yr}^{-1}$ ) to the global emissions of $\mathrm{CH}_{3} \mathrm{Br}\left(\sim 100 \mathrm{Gg} \mathrm{yr}^{-1}\right)$ and to the total pyrogenic flux of this species $\left(\sim 20-30 \mathrm{Gg} \mathrm{yr}^{-1}\right)$. Overall, however, we find that biomass burning contributes significantly to the budgets of stratospheric chlorine and bromine species. The importance of this contribution can be expected to increase as the emission reductions of industrially produced halocarbons take effect.

Acknowledgments. We thank the pilots and crews of the SAFARI-92 research aircraft for their assistance during the research flights, the Kruger Park team (particularly A. Potgieter, W.
Trollope, L. Trollope, and J. G. Goldammer) for their untiring cooperation during the experimental fires in the park, and the team at the sugar plantation at Ubombo Ranches, Big Bend, Swaziland, (especially J. Gosnell and D. Shipley) for their generous help during our experiment. We acknowledge the permission of various government agencies in Angola, Botswana, South Africa, Namibia, Swaziland, Zambia, and Zimbabwe for permission to conduct research in these countries or to use the airspace over these countries. We appreciate the help of T. W. Andreae (logistical support), and U. Parchatka (technical support) during the airborne sampling missions on the DC-3 aircraft. This research was supported by the Max Planck Society.

\section{References}

Andreae, M.O., The influence of tropical biomass burning on climate and the atmospheric environment, in Biogeochemistry of Global Change: Radiatively Active Trace Gases, edited by R.S. Oremland, pp. 113-150, Chapman and Hall, New York, 1993.

Andreae, M. O., Emissions of trace gases and aerosols from savanna fires, in Fire in the Southern African Savannas: Ecological and Atmospheric Perspectives, edited by M. O. Andreae, J. G. Goldammer, J. A. Lindesay, and B. van Wilgen, Witwatersrand University Press, Johannesburg, South Africa, in press, 1996.

Andreae, M.O., G. Helas, S. Manø, G. Schebeske, D. Scharffe, E. Atlas, A. de Kock, W.H. Pollock, R. Koppmann, and J. Rudolph, Methyl halide emissions from savanna fires in southern Africa, Eos Transactions AGU, 74 (43), 117, 1993.

Andreae, M.O., J. Fishman, M. Garstang, J.G. Goldammer, C.O. Justice, J.S. Levine, R.J. Scholes, B.J. Stocks, A.M. Thompson, B. van Wilgen, and the STARE/TRACE-A/SAFARI Science Team, Biomass burning in the global environment: First results from the IGAC/BIBEX field campaign STARE/TRACEA/SAFARI-92, in Global Atmospheric-Biospheric Chemistry: The First IGAC Scientific Conference, edited by R.G. Prinn, pp. 83-101, Plenum, New York, 1994.

Atlas, E., W. Pollock, J. Greenberg, L. Heidt, and A. Thompson, Alkyl nitrates, nonmethane hydrocarbons and halocarbon gases over the equatorial Pacific during SAGA 3, J. Geophys. Res., 98, 16,933-16,947, 1993.

Crutzen, P.J., and M.O. Andreae, Biomass burning in the 
tropics: Impact on atmospheric chemistry and biogeochemical cycles, Science, 250, 1669-1678, 1990.

Crutzen, P.J., L.E. Heidt, J.P. Krasnec, W.H. Pollock, and W. Seiler, Biomass burning as a source of atmospheric gases $\mathrm{CO}$, $\mathrm{H}_{2}, \mathrm{~N}_{2} \mathrm{O}, \mathrm{NO}, \mathrm{CH}_{3} \mathrm{Cl}$, and $\mathrm{COS}$, Nature, 282, 253-256, 1979.

Hao, W.-M., M.-H. Liu, and P.J. Crutzen, Estimates of annual and regional releases of $\mathrm{CO}_{2}$ and other trace gases to the atmosphere from fires in the tropics, based on the FAO statistics for the period 1975-1980, in Fire in the Tropical Biota: Ecosystem Processes and Global Challenges, edited by J.G. Goldammer, pp. 440-462, Springer-Verlag, New York, 1990.

Heidt, L., Whole air collection and analysis, Atmos. Technol., 9, 37, 1978.

Koppmann, R., F. J. Johnen, C. Plass-Dülmer, and J. Rudolph, Distribution of methyl chloride, dichloromethane, trichloroethene, and tetrachloroethene over the North and South Atlantic, J. Geophys. Res., 98, 20,517-20,526, 1993.

Kuhlbusch, T.A.J., M.O. Andreae, H. Cachier, J.G. Goldammer, J.P. Lacaux, R. Shea, and P.J. Crutzen, Black carbon formation by savanna fires: Measurements and implications for the global carbon cycle, J. Geophys. Res., this issue.

Lacaux, J.P., R.A. Delmas, B. Cros, B. Lefeivre, and M.O. Andreae, Influence of biomass burning emissions on precipitation chemistry in the equatorial forests of Africa, in Global Biomass Burning: Atmospheric, Climatic and Biospheric Implications, edited by J.S. Levine, pp. 167-173, MIT Press, Cambridge, Mass., 1991.

Lacaux, J.P., J.M. Brustet, R. Delmas, J.C. Menaut, L. Abbadie, B. Bonsang, H. Cachier, J. Baudet, M.O. Andreae, and G. Helas, Biomass burning in the tropical savannas of Ivory Coast: An overview of the field experiment Fire of Savannas (FOS/DECAFE 91), J. Atmos. Chem., 22, 195-216, 1995.

Laursen, K.K., P.V. Hobbs, L.F. Radke, and R.A. Rasmussen, Some trace gas emissions from North American biomass fires with an assessment of regional and global fluxes from biomass burning, J. Geophys. Res., 97, 20,687-20,701, 1992.

Lefeivre, B., Etude expérimentale et par modélisation des charactéristiques physiques et chimiques des précipitations collectées en forêt équatoriale africaine. Ph.D. thesis, 308 pp., Univ. Paul Sabatier, Toulouse, France, 1993.

Lobert, J.M., D.H. Scharffe, W.M. Hao, T.A. Kuhlbusch, R. Seuwen, P. Warneck, and P.J. Crutzen, Experimental evaluation of biomass burning emissions: Nitrogen and carbon containing compounds, in Global Biomass Burning: Atmospheric, Climatic and Biospheric Implications, edited by J.S. Levine, pp. 289-304, MIT Press, Cambridge, Mass., 1991.

Lovelock, J.E., Natural halocarbons in the air and in the sea, Nature, 256, 193-194, 1975.

Maenhaut, W., I. Salma, J. Cafmeyer, H.J. Annegarn, and M.O. Andreae, Regional atmospheric aerosol composition and sources in the eastem Transvaal, South Africa, and impact of biomass burning, J. Geophys. Res., this issue.

Manø, S., Messung von partiell oxidierten Kohlenwasserstoffen in Emissionen von Biomasseverbrennung. Ph.D. thesis, 120 pp., J. W. Goethe-Univ. Frankfurt, Germany, 1994.

Manø, S., and M.O. Andreae, Emission of methyl bromide from biomass burning, Science, 263, 1255-1257, 1994.

McKenzie, L. M., D. E. Ward, and W. M. Hao, Chlorine and bromine in the biomass of tropical and temperate ecosystems, in Biomass Burning and Global Change, edited by J. S. Levine, MIT Press, Cambridge, Mass., in press, 1996.

Novelli, P. C., K. A. Masarie, P. P. Tans, and P. M. Lang, Recent changes in atmospheric carbon monoxide, Science, 263, 1587-1590, 1994.

Palmer, T.Y., Combustion sources of atmospheric chlorine, Nature, 263, 44-46, 1976.

Rasmussen, R.A., L.E. Rasmussen, M.A.K. Khalil, and R.W. Dalluge, Concentration distribution of methyl chloride in the atmosphere, J. Geophys. Res., 85, 7350-7356, 1980.
Reinhardt, T.E., Chlorinated emissions in smoke from burning forest fuels, master's thesis, 160 pp., Univ. of Wash., Seattle, 1987.

Rowland, F.S., D.R. Blake, and N.J. Blake, Tropospheric and stratospheric measurements of methyl bromide, in Proceedings of the Methyl Bromide State of the Science Workshop (28 October 1993, Washington, DC), p. 14, Methyl Bromide Coalition, Washington, D.C., 1994.

Rudolph, J., A. Khedim, R. Koppmann, and B. Bonsang, Field study of the emissions of methyl chloride and other halocarbons from biomass burning in western Africa, J. Atmos. Chem., 22, $67-80,1995$.

Schauffler, S.M., L.E. Heidt, W.L. Pollock, T.M. Gilpin, J.F. Vedder, S. Solomon, R.A. Lueb, and E.L. Atlas, Measurements of halogenated organic compounds near the tropical tropopause, Geophys. Res. Lett., 20, 2567-2570, 1993.

Schutyser P., W. Maenhaut, and R. Dams, Instrumental neutron activation analysis of dry atmospheric fall-out and rainwater, Anal. Chim. Acta, 100, 75-85, 1978.

Singh, H.B., L.J. Salas, and R.E. Stiles, Methyl halides in and over the eastern Pacific $\left(40^{\circ} \mathrm{N}-32^{\circ} \mathrm{S}\right), J$. Geophys. Res., 88, 3684-3690, 1983.

Stocks, B. J., B. W. van Wilgen, W. S. W. Trollope, D. J. McRae, J.A. Mason, F. Weirich, and A. L. F. Potgieter, Fuels and fire behavior on large-scale savanna fires in Kruger National Park, South Africa, J. Geophys. Res., this issue.

Tassios, S., and D. R. Packham, The release of methyl chloride from biomass burning in Australia, J. Air Pollut. Control. Assoc., 35, 41-42, 1985.

Trollope, W. S. W., L. A. Trollope, A. L. F. Potgieter, and N. Zambatis, SAFARI-92: Characterization of biomass and fire behavior in the small experimental burns in the Kruger National Park, J. Geophys. Res., this issue.

United Nations Environment Program (UNEP), Methyl bromide: Its atmospheric science, technology and economics, Montreal Protocol assessment supplement, 41 pp., Nairobi, Kenya, 1992.

Ward, D.E., R.A. Susott, J.B. Kauffman, R.E. Babbitt, D.L. Cummings, B. Dias, B.N. Holben, Y.J. Kaufman, R.A. Rasmussen, and A.W. Setzer, Smoke and fire characteristics for cerrado and deforestation burns in Brazil: BASE-B experiment, J. Geophys. Res., 97, 14,601-14,619, 1992.

Weisenstein, D.K., M.K.W. Ko, and N.-D. Sze, The chlorine budget of the present-day atmosphere: A modeling study, $J$. Geophys. Res., 97, 2547-2559, 1992.

World Meteorological Organization (WMO), Atmospheric ozone, Global Ozone Res. Monitor. Proj. Rep. 16, Geneva, 1985.

WMO/UNEP, Scientific Assessment of Ozone Depletion: 1991, 350 pp., Geneva, 1992.

WMOUNEP, Scientific Assessment of Ozone Depletion: 1994, WMO, Geneva, in press, 1995.

M. O. Andreae, G. Helas, S. Manø, D. Scharffe, G. Schebeske, and $M$. Welling, Biogeochemistry and Air Chemistry Departments, Max Planck Institute for Chemistry, P.O. Box 3060, 55020 Mainz, Germany (e-mail: moa@mpch-mainz.mpg.de)

E. Atlas and W.H. Pollock, Atmospheric Chemistry Division, National Center for Atmospheric Research, Boulder, CO 80307.

G. W. Harris, Centre for Atmospheric Chemistry, York University, North York, Ontario, Canada M3J 1P3.

A. de Kock, PETCRU, Port Elizabeth, South Africa.

R. Koppmann and J. Rudolph, Institut für Atmosphärische Chemie, Forschungszentrum Jülich, D-52425 Jülich, Germany. W. Maenhaut, Institute for Nuclear Sciences, University of Gent, Proeftuinstraat 86, Gent, Belgium

(Received October 31, 1994; revised April 15, 1995; accepted May 5, 1995.) 